\title{
Building Innovation and Entrepreneurship Model School with Marine Characteristics by "Four-in- one" and "Multi-party Collaboration"
}

\author{
Guangya Zhang \\ Dean's office \\ Guangdong Ocean University \\ Zhanjiang, China \\ zhangguangya@126.com
}

\author{
Lingli Fan* \\ School of ocean and meteorology \\ Guangdong Ocean University \\ Zhanjiang, China \\ *Corresponding author, fanlingli@126.com
}

\begin{abstract}
Guangdong Ocean University has scientifically planned the reform of innovation and entrepreneurship education through improving the system and mechanism. Through the revision of the training program, the innovation and entrepreneurship education and professional education are deeply integrated, which is implemented in the process of personnel training, and lay the foundation for innovation and entrepreneurship education. Through collaboration with the government, research institutes, enterprises and other universities, the practice carrier of innovation and entrepreneurship is built to strengthen the cultivation of students' ability. Through the improvement of safeguard measures, effort to guide and help innovation and entrepreneurship. Constantly strengthening marine characteristics, innovation and entrepreneurship education results are increasingly prominent.
\end{abstract}

Keywords-Four-in-one, Multi-party Collaboration, Marine characteristics, Model school

\section{INTRODUCTION}

Guangdong Ocean University aims to cultivate high-quality professionals and industry elites with international vision and sense of social responsibility [1], with independent learning ability, practical ability and innovative spirit. We take "professional based, curricular development, deeper integration, full time" work ethic, based on the features of the subject, according to the needs of industry, integration of local resources; integrate the innovation and entrepreneurship education into the process of personnel training. Based on the "six classroom" teaching [2], we construct an infiltrative system for cultivating students' innovative and entrepreneurial ability, and to promote the integration of quality education, innovation and entrepreneurship education combined with professional education. Implementation of series of programs of College Students' innovative entrepreneurship training program and campus science and technology cultural activities [3] to strengthen innovation and entrepreneurship education practice. The innovation and entrepreneurship education model of "four in one" and "multi party collaborative education", with marine characteristics, was constructed. Students' entrepreneurial awareness, innovative spirit and innovative ability have been effectively improved, and innovation and entrepreneurship education has achieved remarkable results.

\section{PERFECTING SYSTEM MECHANISM AND SCIENTIFICALLY PLANNING INNOVATION AND ENTREPRENEURSHIP EDUCATION REFORM}

\section{A. Strengthen organizational leadership and promote top- level design}

The school writes "supporting students to carry out scientific research, technological development and innovation and entrepreneurship activities" in "Guangdong Ocean University statute". In "Three action planning", "the high-level university construction planning" and "13th Five-Year development planning ", the school takes 'College Students' innovation and entrepreneurship education project" as the key construction project.

\section{B. Strengthen internal linkage, improve the security mechanism}

The school leadership attaches great importance to innovation and entrepreneurship education, build innovation and entrepreneurship education work leading group, several leaders of the school as group leader and deputy leaders. The dean led many departments make concerted efforts of innovation and entrepreneurship education mechanism, set up the Institute of innovation and entrepreneurship. The colleges have set up the working group for innovation and Entrepreneurship of students.

The school formulated the "implementation opinions of Guangdong Ocean University on strengthening the innovation and entrepreneurship education of undergraduate students'[4], defined the work responsibility, task completion schedule, and overall planning to promote the innovation and entrepreneurship education reform. The school has improved the management system to support the innovation and Entrepreneurship of students from financial support, project support and tutor configuration. Introduce the system of credit accreditation management for undergraduate innovation and entrepreneurship practice, clear innovation credits identification, credit accumulation swap methods. Implement 
credit system, elective system and tutorial system; build a platform to support students to establish scientific research and innovation team standardize the team into the incubation base. Encourage teachers to rely on scientific research projects and lead students to carry out innovative practice. Carry out the reform of the pilot college, explore the protection mechanism which relying on key teams and key laboratories to provide conditions for students' ability to innovate and entrepreneurship.

Setting up innovation and entrepreneurship scholarships to improve the incentive mechanism of innovation and entrepreneurship. The teachers and students with outstanding performance in innovation and entrepreneurship education should be commended and rewarded. The performance of innovation and entrepreneurship education should be integrated into the assessment of teachers in colleges, and teachers should be encouraged to actively participate in innovation and entrepreneurship education.

\section{Promoting "multi -party collaboration" and constructing "school +" innovation and entrepreneurship education model}

The school introduced collaborative management approach in education platform, to promote the establishment and improvement of the cooperative school running mechanism, which takes the school as the main body, the government as the leading factor, the industry guidance and the enterprise's active participation, and forms a deep interactive cooperative education system of the integration of production, education and administration. The first is "school + government", the Guangdong Provincial People's government signed an agreement with the China Ocean Bureau to build Guangdong Ocean University. Second is "school + industry", with the cooperation of China Fisheries Group, fisheries college has trained high-quality marine fishery resources and applied talents [5].

III. REVISING THE TRAINING PLAN AND CONSOLIDATING THE FOUNDATION OF INNOVATION AND ENTREPRENEURSHIP EDUCATION

\section{A. Optimize the curriculum system, and realize the deep integration of innovation, entrepreneurship education and professional education}

Combined with the teaching reform of credit system, the talent training program was revised, and the curriculum system of "general education + professional education + comprehensive practice" was established [6]. The innovative entrepreneurial talent training as a "point", all students' innovation and entrepreneurship training as the "surface", "points" + "face" to implement the "double hundred project". Cultivating students' ability of innovation and Entrepreneurship ('face"), they are required to complete the compulsory general education core curriculums of "innovation and entrepreneurship education", "college Students' occupation development and employment guidance", "professional introduction"; complete the general education development class "research and innovation education module"; in professional education, strengthen the innovation and entrepreneurship education according to the two categories of "basic class" and "application class". Taking teaching reform project and teaching quality project as the carrier, we support subjects to enrich the cases of innovation and entrepreneurship education into teaching, realize the full coverage of innovation and entrepreneurship education. The total credit of training program innovation entrepreneurship education system is 10 . Innovative entrepreneurial talent training ("points"), mainly through the implementation of the "double hundred project" [7]. Each year, 200 excellent students are selected from the freshmen, and focus on the training by two categories, academic and management. It aims to cultivate elite talents with high comprehensive quality, solid theoretical foundation, good discipline quality, strong practical ability, full of scientific and technological innovation spirit, or modern management concept. Setting up the minor major and experimental class of innovation and entrepreneurship education, setting up a special talent training plan, appointing entrepreneurs as mentors, and cultivating targeted students.

\section{B. Strengthening the construction of curriculum resources for innovation and Entrepreneurship}

Through the "independent construction + quality introduction", the school has created "innovation and entrepreneurship" general education optional course group composed of more than 30 courses, such as entrepreneurship and innovation leadership. The school has constructed the network teaching platform, "philosophy wisdom and the innovation thought" is the provincial innovation and entrepreneurship education curriculum. The school has built 29 provincial quality courses, 1 applied talents training courses, 90 excellent courses in the university. The school has introduced 67 high-quality MOOC courses, covering all types of general education optional courses, 27063 students have taken MOOC. "Marine economics" and other marine characteristic innovation and entrepreneurship textbooks published in higher education press.

\section{Promoting the reform of research teaching method}

Through the introduction of "professional introduction", guide students love their major. To promote the teaching methods through the "double hundred project" experimental class reform. Through the establishment of classroom teaching reform, curriculum examination reform and innovation and entrepreneurship education reform projects, the promotion of discussion style, case type, flip class and other ways, guide students to learn independently by using network course resources. By standardizing the management of classroom teaching, the classroom teaching and experimental teaching are improved. The homework, report, class discussion, quizzes and final examination system are improved. These reforms cultivate students' innovative thinking ability, independent reading of professional literature ability, independent writing of papers (reports) ability and the ability to conduct autonomous learning and communication. 
IV. STRENGTHEN THE ABILITY TRAINING, BUILD THE CARRIER OF INNOVATION AND ENTREPRENEURSHIP PRACTICE IN MANY WAYS

\section{A. Improve the training plan system of innovation and Entrepreneurship}

The school has established the national, provincial, university three level of innovation and entrepreneurship training program system, created "Guangdong Ocean University innovation and Entrepreneurship Week", to promote the transformation of innovative projects and incubation of entrepreneurial projects. In the past 2013-2017, 766 projects of innovation and entrepreneurship training program for students were set up, and the funding was $¥ 4420000$. To carry out the "sea sail program" students' scientific and technological innovation cultivation project, select excellent projects, so that they declare Guangdong province college students' scientific and technological innovation cultivation projects (climbing plan). In the past 2015-2017, 41 projects have received provincial project funds of $¥ 855000$.

\section{B. Construction of innovation and entrepreneurship practice base}

The school has established 320 out of school practical teaching bases with enterprises, institutions, research institutes and government departments. One national undergraduate practice teaching bases and 17 provincial universities have been built. Every year, more than 9000 students enter the base to take part in the practice. The school has a student incubator for innovation and entrepreneurship (800 square meters), business incubator for entrepreneurship and employment (300 square meters), student science and technology park (500 square meters). The school has worked with the bureau of human resources and social affairs in Zhanjiang to build "students collaborative innovation vocational skills training base". More than 150 entrepreneurial teams have been registered, with 68 registered companies, and more than 1000 students have been enrolled.

\section{Carry out innovation and entrepreneurship simulation training}

Carry out "four aspects, six combinations" innovation and entrepreneurship simulation training. The four aspects include: SYB entrepreneurship training; entrepreneurial forum and entrepreneurs into the campus; "brand" project of college innovation and entrepreneurship education; entrepreneurial competition and communication; entrepreneurial incubation. Six combinations include: combining SYB standard entrepreneurship training curriculum and the localization of entrepreneurship curriculum; entrepreneurial training programs and courses; promoting entrepreneurship incubation; classroom learning and discussion; online and offline; the classroom and extracurricular practice. In the past three years, SYB has trained more than 1300 students, the school holds more than 40 activities, such as innovation and entrepreneurship forum, entrepreneurship platform, entrepreneurship guidance, entrepreneurship promotion meeting, with more than 8000 students participating. More than 10 professional associations of innovation and entrepreneurship have been established, such as "employment and entrepreneurship assistance association", "entrepreneurial association" and so on. For nearly three years, held seminars, salon innovation more than 80 games, more than 20 thousand students to participate, organize students to carry out entrepreneurship training 5 times, more than 800 students involved, 3 students selected in Guangdong plan of guiding college students' innovation and entrepreneurship.

\section{Carry out innovation and entrepreneurship activities of competitive products}

The marine science and technology festival as the main carrier, the school held college students' innovation and entrepreneurship competition of "Internet+", "Challenge Cup" extracurricular scientific and technological works competition for college students, professional competition, IT science and technology festival etc. The school sent outstanding projects in provincial and national competition, through the "combination of teaching and learning, learning in competition, promoting teaching and learning by competition", combining innovation and entrepreneurship with teaching and scientific research, training innovative and entrepreneurial talents. In the past three years, "Challenge Cup", mathematical modeling, English reading and writing contest have been held. More than 3500 students have participated in the "Challenge Cup", and the number of entries has reached 698.

\section{E. Establishing extracurricular innovation and entrepreneurship team}

First, the school supports students to set up associations, to carry out innovation and entrepreneurship practice, at present there are 66 academic, scientific and technological innovations, entrepreneurship and other associations, there are more than 15800 members. Second, set up special funds to support students to set up innovation and entrepreneurship team, engaged in scientific research, invention and product creation, under the guidance of teachers. For example, Fisheries College developed selection and assessment methods for excellent undergraduate into the laboratory provide funds, students independently selected topics, the results were rewarded. Since 2014, 188 projects of science and technology innovation have been set up, 63 papers have been published and one patent have been authorized. In the second national innovation and entrepreneurship competition of life science majors, won 6 second prizes, 2 third prizes, one excellent organization award. For another example, electronic and information engineering college build 12 long-term stable student sciences and technology team, "Mathematical Modeling Contest" is guided by curriculum and association. In the past three years, in the electronic design contest, smart car competition, the challenge cup competition, there are 8 students received international awards, 37 students received national awards, 148 students won provincial awards, 197 students received the award. 
V. IMPROVE SAFEGUARD MEASURES, DO A GOOD JOB OF INNOVATION AND ENTREPRENEURSHIP GUIDANCE AND ASSISTANCE

\section{A. Optimizing incentive oriented teaching management}

The implementation of the credit system and the elastic limit (the longest 8 years of study, innovation and entrepreneurship, excluding the time), allowing students to retain their status, suspend school, and start their own businesses. The school issued undergraduate innovation and entrepreneurship practice credit accreditation management measures and other documents. The subject competition, published professional papers, patents and self - employment of students can be converted to the highest 6 credits. Support students to participate in innovation and entrepreneurship competition through funding, reward and other methods. In the selection of advanced, pushing the avoidance of selection, emphasizing the spirit and ability of innovation, innovation and entrepreneurship outstanding performance will be recommended exemption graduate. The school also introduced second professional and double degree personnel training mode implementation measures to meet the needs of students' diversified growth, enhance their social competitiveness.

\section{B. Setting up a full-time and part-time teachers team}

A full-time team of entrepreneurial education is formed by the faculty of economics and management, a full-time institution for entrepreneurship guidance is set up. Implementing the "three major teacher training programs" which composed of expert plan, mentor plan and consultant plan. The "professional teacher" team of industry experts and excellent lecturers has been established, and the "double tutor" system has been perfected.

Issued a document allowance distribution method, subsidies are given to the teachers who offer innovative courses and guide the students' innovation and entrepreneurship training, and the performance of innovation and entrepreneurship education is incorporated into the post appointment and professional promotion conditions of teachers.

Set up special research on innovation and entrepreneurship, and guide teachers to carry out innovation and entrepreneurship education reform and practice combined with their own work. Undertake 3 provincial and 10 university innovation and entrepreneurship training projects, 8 provincial and 64 university innovation and entrepreneurship education projects were carried out in 8 and 64 universities, and 36 papers were published in all levels of journals, among which 3 were core journals.

\section{Multi-channel financial support to support students' innovation and entrepreneurship activities}

The school integrates innovation and entrepreneurship into the annual budget and provides sufficient financial support for the students' innovation and entrepreneurship activities. The special funds for innovation and strengthening school project is $¥ 1800000$, and the special fund for innovation and entrepreneurship education reform project is $¥ 836300$. The funds for innovation and entrepreneurship training program for college students are $¥ 2870000$, $¥ 1100000$ for college students (subject) innovation fund, $¥ 1065000$ for academic disciplines competition, and $¥ 90000$ for youth employment and entrepreneurship base construction, Provincial SYB fixed-point training funds of $¥$ 837000, Enrollment and Employment Guidance Center Department fund about $¥ 1000000$, innovation and entrepreneurship special funds $¥ 794200$, absorb enterprise donation funds to establish various types of scholarships, reward 143 students, the total amount of $¥ 455000$.

\section{TO CREATE MARINE CHARACTERISTICS, INNOVATION AND ENTREPRENEURSHIP EDUCATION ACHIEVEMENTS HAVE BECOME INCREASINGLY PROMINENT}

Guangdong Ocean University takes improving the quality of personnel training as the core, the innovative talent training mechanism as the focus, the conditions and policy as a support, the innovation and entrepreneurship education model of "Fourin-one" and "Multi-party Collaboration" is constructed, more and more achievements have been achieved.

\section{A. Perfect supporting system}

Four levels progressive of "Consciousness training + ability promotion + project incubation + professional service" [8] for innovation and entrepreneurship education system should be established to enhance the breadth and depth of innovation and entrepreneurship education. "Consciousness training" mainly refers to the integration of innovation and entrepreneurship education concept into the process of teaching, to cultivate students' independent and critical ability, and enhance innovation and entrepreneurship awareness. "Ability promotion" is to improve students' innovative and entrepreneurial skills through students' innovative entrepreneurship training plan, entrepreneurial simulation practice, etc. "Project incubation" is to build "college students' innovation and entrepreneurship incubator base", "college students science park", "public creative space" and other business incubation chain, to promote the transformation of students' innovative projects, entrepreneurship project incubation. "Professional service" refers to the construction of marine science and technology achievements transfer center [9], to create college student incubator base, scientific and technological achievements transformation center, entrepreneurial "Three-in-one" innovation and entrepreneurship platform. Relying on the advantages of disciplines and Zhanjiang's regional advantages and marine industry resources, the school strengthens the 'University, enterprise, government, society" multi linkage, build a platform for deep collaborative innovation.

\section{B. Rich support platform}

The school has national off campus practice teaching bases, provincial collaborative innovation and education platform, the provincial fixed-point SYB entrepreneurship training institution, the Guangdong Provincial Communist Youth League college students "green space" incubator center demonstration, the first batch of "public innovation, entrepreneurship" demonstration base of Guangdong development and reform commission,, China "maker space " pilot unit of Guangdong department of science and technology 
and the torch high tech industrial development center of the ministry of science and technology.

\section{Great achievements in innovation}

In the past three years, students have won 1323 awards, including 10 international awards, 813 national awards and 500 provincial awards. In 2015, the school organized 5 teams to participate in the international student modeling contest for the first time, and won one first prize, 2 second prizes and 2 third prizes. The students have published 1074 papers and applied for 259 patents. Two published papers were selected by the seventh and the ninth National College Students' innovation and entrepreneurship annual conference, "The effect of salinity on the early development of gray leaf sargassum ovulation and young sporophyte" and "Effects of several lutein recipes on behavior and performance of laying hens in high temperature and humidity environment", the first author of two papers are student.

\section{Typical demonstration of entrepreneurship}

In the past 3 years, students have won 1 first prizes, 12 second prizes and 15 third prizes in the "Challenge Cup youth" Guangdong college students entrepreneurship competition. In the Fifth China Innovation and entrepreneurship competition and the third cross-strait four places college students' innovation and entrepreneurship competition finals, cloud era team ranked third in the finals, the first in the mainland group, won the second prize. In the incubated enterprises "Zhanjiang Youjia Network Technology Co., Ltd. ", listed in the "China Innovation Board" authorized by the Guangzhou equity trading center. In the first venture competition in Zhanjiang, our students won all the first prizes, won 13 awards (total is 30 awards). In the first "Wanda SOHO youth" Zhanjiang youth entrepreneurship competition, our entrepreneurial team won the "Gold Award" and "Scene best Popularity Award". King Village e-commerce team won the championship of luxury car race. Huang Guojun (the 2009 economic management graduate) founded the company, listed in Hongkong, the total assets of more than 5 billion Hong Kong dollars. Li Wenxiang (2011 software engineering graduate), established the largest microblog marketing promotion company in Guangzhou, at the same time run its own brand "WIS", the annual turnover is more than one hundred million yuan. Chen Kang (2010 graduate) founded the company to become the WeChat public number operating company in the domestic top five user level. Zeng min (2006 animal medicine graduate) founded the company, with an annual output value of more than two hundred million yuan.

In recent years, the employment satisfaction of our graduates is above $90 \%$, graduate employment satisfaction and entrepreneurial rate increased year by year, employment quality has become better, and the employment rate has been higher than the average of Guangdong. The school employment and entrepreneurship guidance team was rated as an excellent team of college students management in Guangdong. The school won "the outstanding organization award" and "best Popularity Award" in "Bohui Cup" entrepreneurship contest. The mode of cooperation between our school and social enterprises to build the incubation base for business incubator is called a new mode of entrepreneurship for college students in Zhanjiang by "Yangcheng Evening News". The experience of the reform and innovation of talent training mode in our university has been reported by authoritative media, such as China Education Daily, China Ocean News and Nanfang daily.

\section{ACKNOWLEDGMENT}

Fund Projects: Project supported by college teaching quality and teaching reform project construction project in Guangdong, the Education Department of Guangdong province, 2016(233), Exploring and practicing the training mechanism of "double innovation" by taking the reform of classroom teaching as a breakthrough point, 2018(1) , project supported by college teaching quality and teaching reform project construction project in Guangdong, the Education Department of Guangdong province.

\section{REFERENCES}

[1] Constitution of Guangdong Ocean

Universit,http://www2.gdou.edu.cn/hdwj/2014/d201475.htm,unpublishe d. (In Chinese)

[2] The work plan of building "Public Entrepreneurship, Innovation" demonstration base in Guangdong Ocean University(20162018),http://www2.gdou.edu.cn/hdwj/2016/zsjy2160019.htm ,unpublish ed. (In Chinese)

[3] Implemented plan of Communist Youth League reform in Guangdong Ocean University, http://www2.gdou.edu.cn/hdwj/2017/d201756.htm. (In Chinese)

[4] Opinions on strengthening the innovation and entrepreneurship education for undergraduates in Guangdong Ocean University,http://www2.gdou.edu.cn/hdwj/2015/jw2150122.htm,unpubli shed.(In Chinese)

[5] Zhang Guangya,Fan Lingli, Exploration and Practice on the Cultivation of Innovative Talents in Local Universities. (sumitted)

[6] Zhang Guangya,Fan Lingli,The Optimization of Curriculum System of Innovation and Entrepreneurship Education in Local Universities. (sumitted).

[7] The "double hundred project" undergraduate training mode reform in Guangdong Ocean University. http://www2.gdou.edu.cn/hdwj/2010/x210016.htm. (In Chinese)

[8] Zhang Guangya, Fan Lingli, Thin king on the Practice Teaching Reform of Local Universities under the Background of Innovation and Entrepreneurship Education. (sumitted).

[9] TWang Zhongbing chaired the forum of the Huguang innovation circle planning construction work, http://news.gdzjdaily.com.cn/zjxw/content/2017/02/05/content_2194070 .shtml. (In Chinese) 